\title{
Understanding the Determinants of Penal Policy: crime, culture and comparative political economy
}

Nicola Lacey, David Soskice and David Hope

Working paper 13

July 2017 


\section{LSE International Inequalities Institute}

The International Inequalities Institute (III) based at the London School of Economics and Political Science (LSE) aims to be the world's leading centre for interdisciplinary research on inequalities and create real impact through policy solutions that tackle the issue. The Institute provides a genuinely interdisciplinary forum unlike any other, bringing together expertise from across the School and drawing on the thinking of experts from every continent across the globe to produce high quality research and innovation in the field of inequalities.

For further information on the work of the Institute, please contact the Institute Manager, Liza Ryan at e.ryan@lse.ac.uk.

International Inequalities Institute

The London School of Economics and Political Science

Houghton Street

London

WC2A $2 A E$

Email: Inequalities.institute@Ise.ac.uk

Web site: www.Ise.ac.uk/III

@LSEInequalities

f LSE Inequalities

(C) Nicola Lacey, David Soskice, David Hope. All rights reserved.

Short sections of text, not to exceed two paragraphs, may be quoted without explicit permission provided that full credit, including $\odot$ notice, is given to the source. 


\section{Abstract}

This review sets out four main explanatory paradigms of penal policy-focusing on, in turn, crime, cultural dynamics, economic structures and interests, and institutional differences in the organisation of different political economies as the key determinants of penal policy. We argue that these paradigms are best seen as complementary rather than competitive, and present a case for integrating them analytically in a comparative political economy framework situated within the longue durée of technology regime change. To illustrate this, we present case studies of one exceptional case-the United States-and of one substantive variable-race. Race has been thought to be of importance in most of these paradigms and provides a pertinent example of how the different dynamics intersect in practice. We conclude by summarising the explanatory challenges and research questions that we regard as most urgent for the further development of the field, and point to the approaches that will be needed if scholars are to meet them.

Keywords: Punishment; comparative political economy; race; institutions; social theory

\section{Editorial note}

A revised version of this paper will appear in the Annual Review of Criminology, Vol. $1,2018$. 


\section{Introduction}

Analysis of the wide array of factors that shape penal policy looms large in many of the great social theories that laid the foundations of the modern social sciences. As David Garland (1990) was able to show in his elegant exploration of these traditions, a concern with the role of punishment in the production, reproduction and selfunderstanding of modern social orders not only featured explicitly in Weber's analysis of modern societies and in Durkheim's sociology, but could be drawn out of Marx and Engels' historical materialism-as was reflected in Rusche and Kirchheimer's monumental Punishment and Social Structure in 1939. Norbert Elias's magisterial The Civilising Process (1939); Foucault's theorisation of sovereign and disciplinary power, and their historical trajectories, in the penal context (1977); the great works of anthropology or philosophical psychology such as those of Malinowski (1926) or Mead (1918): all either have things to say, or can be drawn upon to produce insights about, the social roles of punishment and what influences punishment's shape and extent.

Interestingly, however, the same cannot be said to quite the same extent, for much of the twentieth century, of criminology. Perhaps most obviously, this is because during its first decades, approaches working on what we could broadly understand as criminological questions were preoccupied primarily with crime and its determinants, generating debates which, certainly, had implications for penal policy, but were not concerned directly with the causal mechanisms shaping the production of that policy. (It was, after all, called 'criminology' not 'penology'.) The penological branch of criminology, if we may put it in that way, concerned itself mainly with the actual shape and effects, or the reform and invention, of penal and correctional mechanisms, and with the organisation of the professions and bureaucracies which gave penal practices shape. Certainly, the ideas about crime which emerged through criminology were a key factor. Radzinowicz and Hood's authoritative volume The Emergence of Penal Policy in Victorian and Edwardian England (1990) portrays the gradual development of penal policy as a specialist governmental field in the modern administrative state as strongly shaped by changing ideas about the nature of crime and of particular categories of offender, as much as by overarching public philosophies of punishment associated with reformation, deterrence, incapacitation or retribution. The very emergence of penal policy as a field is, after all, premised on a range of influential ideas on modern political philosophy, most notably those of Beccaria (1764) and Bentham (1781). But the notion that there might be something of a general explanatory nature to be said about what determines penal policy in different contexts remained, for much of the twentieth century, unexplored.

This began to change in the 1960s, stimulated in part by labelling theory (Becker 1963), which called into question the standard assumption that penal policy was a rational state response to crime (however understood). It did so by positing a causal link between punishment and crime rather than the other way around, implying that 
the social practices of criminalisation and punishment were playing broad societal roles, and hence driven by broad political-economic forces that helped to explain the policy decisions that were the proximate causes of penal practices. Moreover, the publication in 1968 of a new edition of Rusche and Kirchheimer's classic text was both a cause and a symptom of a reawakening interest in the conditions of existence of penal practices. By the 1980s, a number of influential scholars were publishing work which engaged in a much broader way with the importance of social, political, cultural and economic forces in shaping penal policy, ranging from Dario Melossi and Massimo Pavarini's The Prison and the Factory (1981) and Garland's Punishmentand Welfare (1985) to David Downes' Contrasts in Tolerance (1988). Moving on from the structural materialism of Rusche and Kirchheimer-but also broadening their focus beyond the mechanisms of penal policy such as sentencing, prosecution and the design of penal orders - these scholars began to explore a wide range of social dynamics and institutions that influenced the development of penal policy in different countries, as well as of the political and social discourses within which penal policy is framed and legitimated. This emerging body of work is nicely evoked by the title of Michael Tonry's key review essay, Determinants of Penal Policies, published in 2007.

It seems safe to speculate that this burgeoning of interest in the conditions of existence of penal policy may have been stimulated by two further features of policy and practice from the 1970s on. First, many advanced democracies saw a substantial rise in punitiveness as measured by both imprisonment rates and, a more complicated matter, the intensity of carceral and non-carceral penalties, during the last three decades of the Twentieth Century. This increased scholarly and political focus on punishment as a relatively discrete object of study (as reflected in the establishment of the journal Punishmentand Societyin 1999). Second, notwithstanding the practical challenges of comparative research, there was a gradual realisation among scholars of penal policy that, notwithstanding a widespread increase in punitiveness, otherwise relatively similar countries had developed their penal policies in strikingly different ways, as shown in Figure 1 (Downes 1988; Cavadino \& Dignan 2006; Tonry (ed.) 2007; Lacey 2008). 
Figure 1. Imprisonment trends in advanced economies, 1950-2016

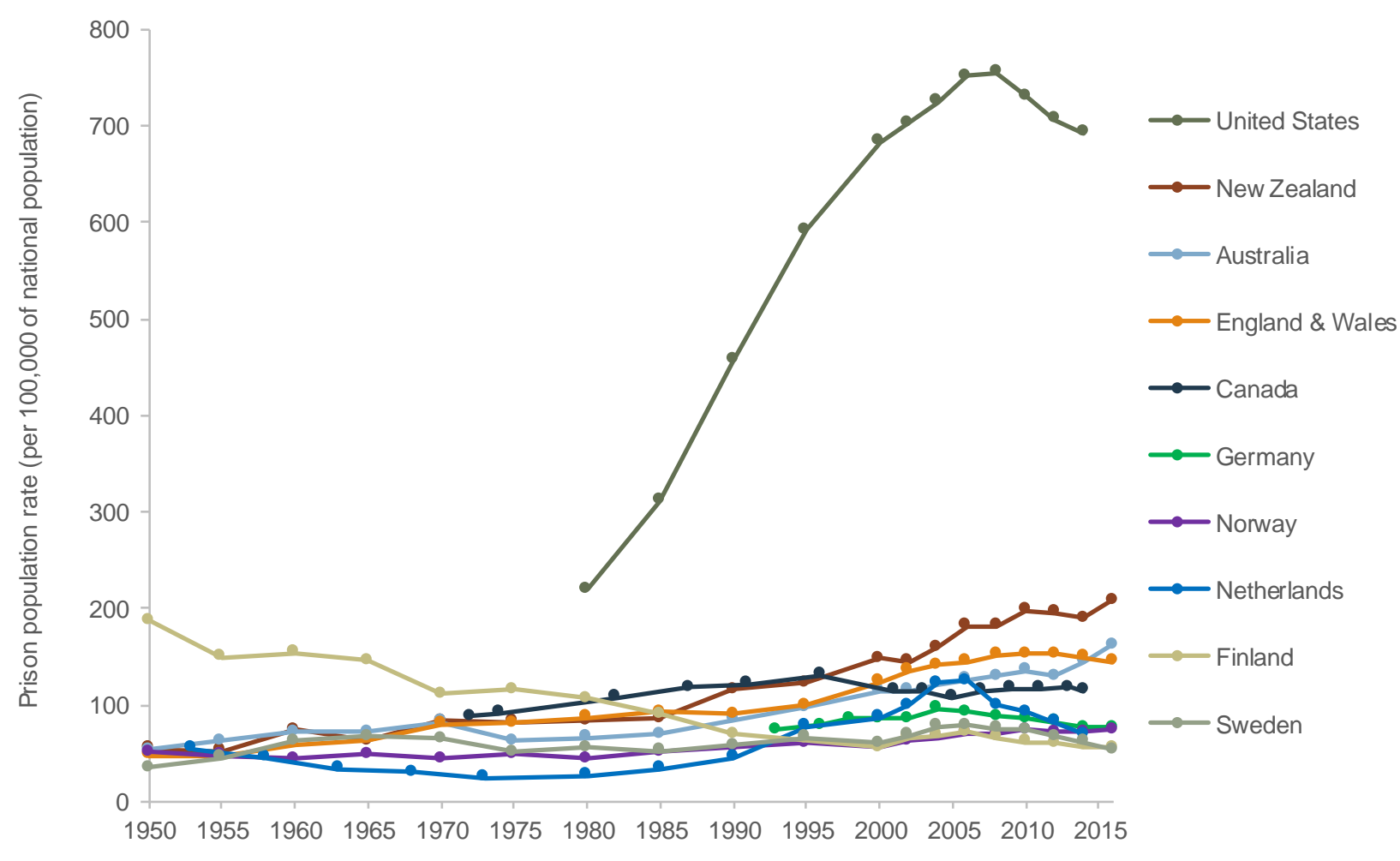

Source: World Prison Brief, Institute for Criminal Policy Research (accessed Jan 2017).

In particular, the United States had seen an explosion of imprisonment rates which had moved it into a category of punitiveness more akin to- indeed yet more extreme than - that of countries without a lengthy tradition of peaceful democratic government than to that prevailing in even the most punitive of other advanced democracies. Russia and, perhaps most interesting, South Africa, are intriguing potential comparators here, with South Africa's 2016 imprisonment rate per hundred thousand (291), like Brazil's (307 (at the end of 2014)) less than half, and Russia's (439), just under two thirds, of the US rate of 666 (at the end of 2015). New Zealand-the most punitive of the advanced economies as measured by imprisonment rates-stands at just 210 , less than a third of the US rate. ${ }^{1}$ The recognition of these comparative differences has acted as a spur to the development of a range of explanations for what determines penal policy, and comparative questions and scholarship will accordingly feature prominently in this review. As the bulk of the existing literature is concerned with the advanced democracies, our main focus will be on them; but we will draw out the research questions which the existing literature suggests would be worthy of pursuit in relation to regions and countries thus far less thoroughly studied. And, we will pay particular attention to what can be learned from the story of the United States as an increasing outlier during the period under consideration.

\footnotetext{
${ }^{1}$ World Prison Brief, Institute for Criminal Policy Research (accessed Jan 2017).
} 
The structure of the review is as follows. In the sections below, we give a succinct account of four main explanatory paradigms-crime, cultural dynamics, economic structures and interests, and institutional differences in the organisation of different political systems and economies as the key determinants of penal policy. Many existing accounts blend these paradigms, which are certainly not mutually exclusive, but it will be nonetheless be useful for the purposes of clarifying different possible emphases to separate them out analytically. To illustrate their interconnections, however, we also present two case studies. First, we examine one striking case-the United States, which as Figure 1 suggests is an outlier in terms of the scope and severity of its penal policy as compared with other advanced economies. Second, we examine one substantive variable - that of race-which has been thought to be of importance in most (but not all) of these paradigms, in order to show how the different dynamics intersect in practice. In these case studies, we use the analytic framework of comparative political economy to embed these intersecting dynamics; and we elaborate subsequently on this approach. Finally, we summarise the research questions that we regard as most urgent for the further development of the field.

\section{Penal Policy as Shaped by Crime}

Perhaps the most obvious candidate for an explanation for how penal policy develops lies in crime: after all, the politicians, policy experts and practitioners in the criminal justice system, who create, shape and interpret penal policy, regularly articulate their concern with crime, as well as operating within an institutional framework explicitly justified as a response to crime, understood variously as harmful, wrongful, pathological and/or costly forms of behaviour. Of course, their information about or perceptions of crime-a notoriously slippery concept (Reiner 2016) —may be variously incomplete, distorted, or self-serving. But the idea that crime does not constitute an important determinant of penal policy would seem, on the face of it, counter-intuitive.

Just such a counter-intuitive position has, however, assumed a prominent position in the field over the last fifteen years, with some of the most influential scholars arguing that penal policy is driven primarily by political considerations, with appeals to crime merely a tool for electoral advantage. These scholars have suggested that the degree of attention given to crime rates is a function of the degree to which politicians find that law and order policies can be manipulated so as to maximise support for other valued goals, whether the covert consolidation of racial inequity (Beckett 1997; Zimring \& Hawkins 1997; Western 2006; American Academy of Arts and Science 2010; Scheingold 2010), the diversion of attention from the limited economic capacity of states in an increasingly interdependent world (Garland 1996), or, most commonly, winning elections. A representative recent example is the following assessment from the National Research Council's report on The Grouth of Incarceration in the United States: Causes and Consequences (2014: 24; see generally Chapter 4 104-29): 
... over the four decades when incarceration rates steadily rose, U.S. crime rates showed no clear trend: the rate of violent crime rose, then fell, rose again, then declined sharply. The best single proximate explanation of the rise in incarceration is not rising crime rates, but the policy choices made by legislators to greatly increase the use of imprisonment as a response to crime.

The plausibility of such claims has been reinforced by appeal to figures tracking imprisonment against homicide rates, showing imprisonment rates continuing to rise long after the marked decline in violent crime, as indicated by homicide rates, in most advanced democracies from the 1990s on (as shown in Figure 2).

Figure 2. Imprisonment and homicide trends in the United States, the United Kingdom, Germany and Norway, 1950-2010

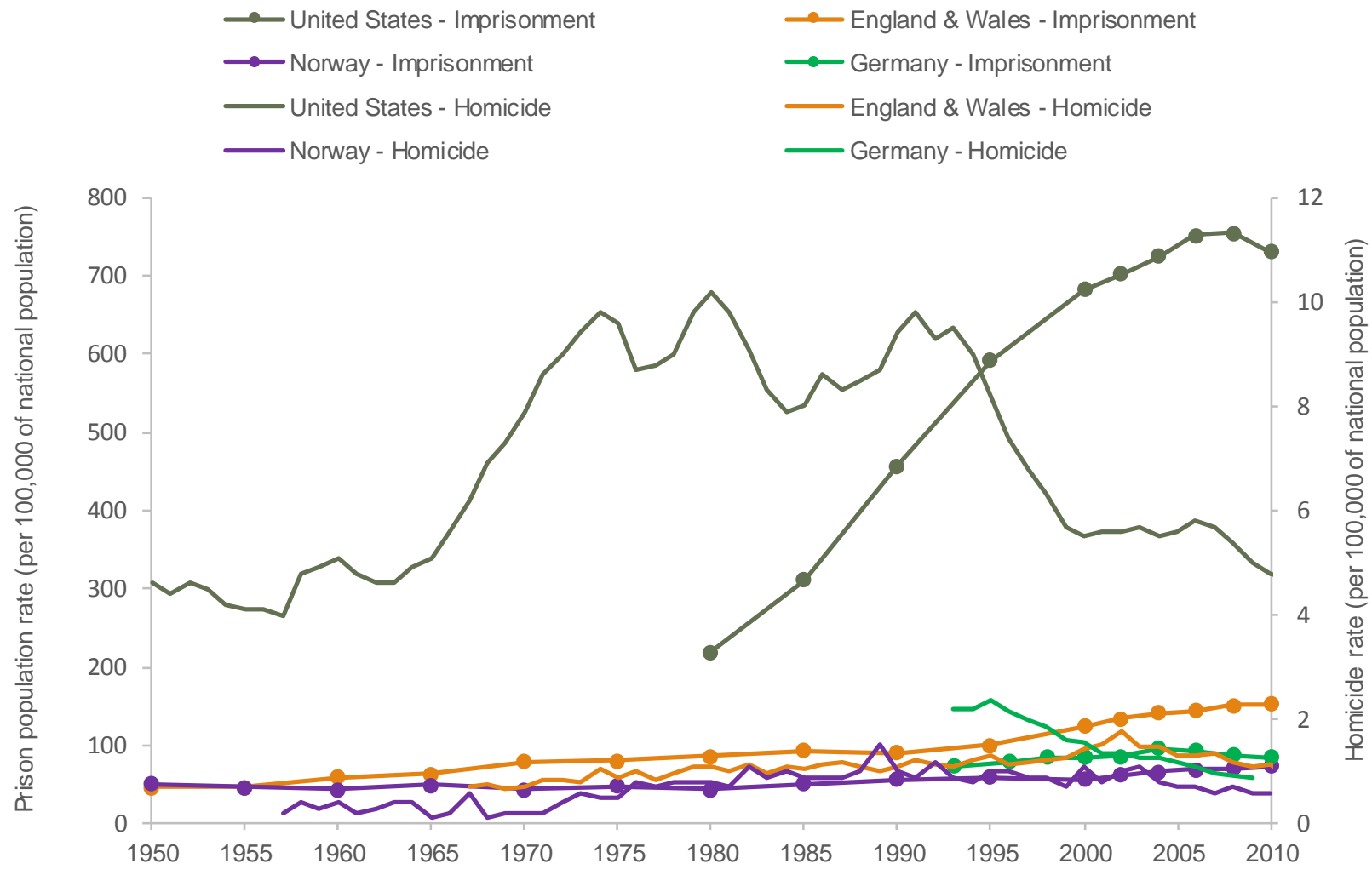

Source: World Prison Brief, Institute for Criminal Policy Research (accessed Jan 2017); United States Federal Bureau of Investigation, Uniform Crime Reporting (accessed Jan 2017); United Kingdom Office for National Statistics (accessed Jan 2017); von Hofer et al. (2012); Bundeskriminalamt, Police Crime Statistics (accessed Jan 2017); Birkel \& Dern (2012).

A superficial reading of these figures is, however, misleading. First, one would expect a significant time lag between a decline in crime and a decline in imprisonment: release rates do not correlate to admissions rates, and particularly in a system with many very long sentences, a decline in the rate of people sentenced will take a considerable time to show up in the imprisonment rate (Pfaff 2012). Hence the relevant measure should be not the imprisonment rate itself but the rate of change in that rate: the measurement 
most directly affected by variations in penal policy. And while the National Council is right to point out that the proximate driver of the imprisonment rate consists in the policy choices of legislators (and indeed, particularly in the United States, other elected officials), the question of the extent to which those choices are themselves shaped by perceptions of crime-or about voters' perceptions of crime-is an important one an answer to which should be framed on the basis of evidence. A recent careful econometric study of the American data by political scientist Peter K. Enns (2016), shows in fact that violent crime rates are indeed closely correlated, at least in the US, not only with the development of penal policy as measured by the rate of change in the imprisonment rate, but also with public levels of punitiveness (again carefully measured), which would seem likely to be a key driver of politicians' electoral concern to develop effective penal policies (see Figure 3). Particularly telling is Enns' meticulous deconstruction-on the basis of both statistical analysis and archival research-of the widely made claim that the Republicans' law and order policies, including the War on Drugs, were premised primarily on race-related goals rather than a more general sense of the concern of rising crime rates across the electorate. Enns shows that politicians from Johnson via Robert Kennedy to Nixon adapted their policy slates in response to polling data on concern about crime among the population, rather than manipulating public opinion via law and order campaigns to legitimise racially targeted exclusionary policy-making.

Figure 3. Public support for being tough on crime, changes in the incarceration rate and the violent crime rate in the United States, 1960-2010

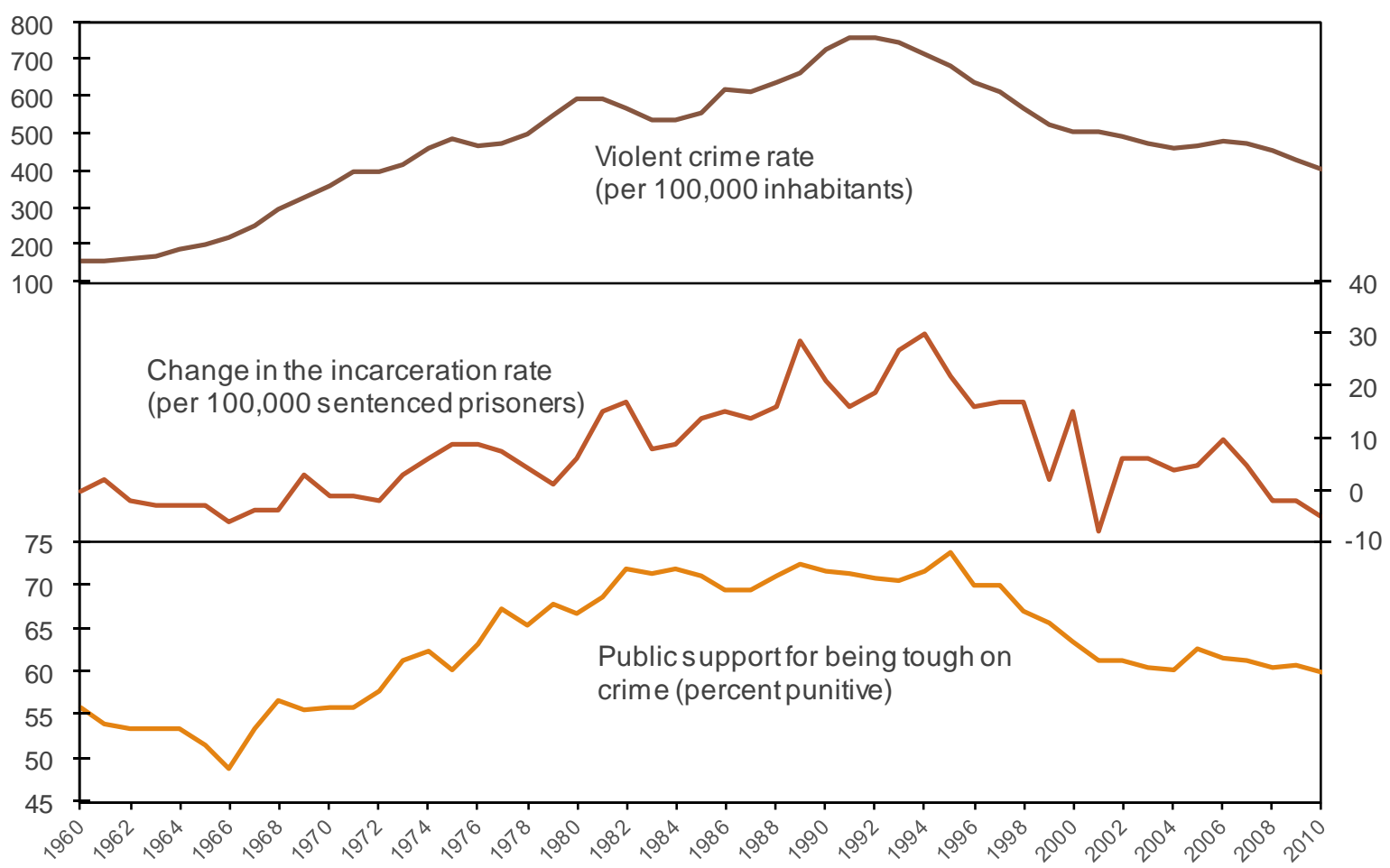

Source: Enns (2014); United States Federal Bureau of Investigation, Uniform Crime Reporting (accessed Jan 2017). 
This is, of course-as we shall see-not to say that race can be ruled out as a factor influencing penal policy. And certainly, as Reiner (2007) has shown in relation to England and Wales, the correlation between crime, and public perceptions of crime, and punishment, is complex. This is because crime is not the only factor which shapes penal policy via political concern, and because the information on which policy is based may not be accurate or may be distorted in many ways, not least-as both Enns and Reiner acknowledge-by media representations. But the best evidence and analysis currently available supports the view that crime rates, public levels of concern about crime, and politicians' perceptions of both these factors, are one important determinant of penal policy (Garland 2001, 2017). Moreover, concern about particular kinds of crime-notably serious violence-has a special political salience that may help to explain differences among relatively similar countries, and in particular, the outlier status of the United States, whose levels of serious violent crime have long exceeded those of obvious comparator countries such as the United Kingdom or Australia (Roth 2009; Lacey \& Soskice 2015; Miller 2016; Gallo et al. 2017). However, varying crime rates certainly cannot explain the full extent of national variations in penal policy; hence we need to review paradigms which give us a broader grasp of what shapes the way in which the basic facts of offending behaviour are perceived and interpreted in the flow of social communications and political decision-making. As the National Research Council report (2014: 105) puts it:

Although rising crime rates are a key part of this story, it is only by examining those trends within their social, political, institutional, and historical context that one can understand the underlying causes of the steep increase in incarceration rates.

\section{Penal Policy as Shaped by Cultural Dynamics}

Another strand in the comparative literature focuses on cultural differences (Cusac 2009; Nelken 2010, 2016; Tonry 2004). Most scholars accept that the history of penal policy development has been importantly shaped by ideas. Think, for example, of the ways in which Beccarian (Beccaria 1764) and Benthamite (Bentham 1781) theory resonated with the broader reformist project of modernisation, rationality and standardisation in government; or the role of a variety of religious traditions and protopsychiatric theories in shaping policy in a range of spiritually or quasi-medically driven ameliorative projects in the $19^{\text {th }}$ Century. The history of penal philosophy and social ideas has accordingly played a significant role in scholarship on the evolution of penal policy (Rothman 1971; Ignatieff 1978; Spierenburg 1984; Garland 1985; Radzinowicz \& Hood 1990; Gatrell 1994). The attitudes, beliefs and expectations which make those ideas appealing or persistent therefore present themselves as an interesting focus for the scholar of penal policy.

Cultural arguments are notoriously difficult to pin down, not least because they come in many different forms. But a useful way of understanding them, and how they differ 
from purely structural or institutional explanations, is to see that cultural explanations focus on the symbolic, affective and/or communicative dimensions of both punishment and policy-making, and seek to give us a better grasp of the conditions under which particular penal policies are likely to be regarded as legitimate or appealing. Hence it is argued that the cultural dynamics surrounding penal policy-making and practices of punishment can help us to understand both how policy preferences are shaped and how particular policies may become stabilised even under material conditions which might be thought to affect or undermine their rationale. So, for example, if Durkheim $(1893,1902)$ was right in his somewhat counter-intuitive view that crime is a healthy thing precisely because it provides the occasion for an expressive reassertion, through the imposition of punishment, of the conscience collective which binds society together, then we might expect penal policy choices to be shaped by a concern for popular legitimation and expressive appropriateness rather than by rational calculations of the prospects for deterrence, reform or incapacitation. Moreover, we might expect longstanding attachments within particular groups to certain values or self-identities to shape the perception of the fairness or otherwise appropriateness of penal policies, potentially explaining differences in penal policy between countries with relatively similar crime problems and political and economic systems. One of the most famous cultural accounts of punishment has been drawn by David Garland (1990) out of Norbert Elias's The Civilising Process (1939) - a historical explication of the emergence and diffusion of norms of civility including the increasing proscription of violence, particularly in public. This, Garland argues, was of key importance for the radical change in the forms of punishment away from corporal and capital penalties towards carceral penalties imposed behind the walls of the modern prison.

In evaluating the impact which cultural explanations have had on the study of penal policy, a useful focus is the current debate about so-called 'Nordic Exceptionalism' in punishment. In a wide-ranging two-part article (Pratt $2008 \mathrm{a}, \mathrm{b}$ ) and a book (Pratt \& Eriksson 2013), John Pratt and Anna Eriksson have argued that, amid some key institutional differences between the Nordic and other Western European systems, these countries' small size and long history of interdependence within an agricultural economy organised in relatively small communities has fostered a culture of solidarity and mutual responsibility, as well as high levels of trust (see also Tonry and LappiSeppälä (eds.) 2012). These cultural features of Nordic life have, it is argued, fundamentally affected the climate in which penal policy is formed. While politicaleconomic factors also matter, Pratt \& Eriksson (2013) argue strongly that a distinctive cluster of cultural attitudes has made an independent difference to popular attitudes about appropriateness in punishment-attitudes which, particularly in relation to insiders (Lacey 2008), helped to legitimise and stabilise the penal moderation that is the hallmark of these countries. These attitudes held up during a period in which violent crime was rising and many of their west European neighbours were opting for more punitive penal policies in terms of both scale and quality. Vanessa Barker (2013), joining the debate to caution against too rosy a view of Nordic exceptionalism, has relied on cultural dynamics in pointing out that the wide assumption of mutual 
responsibility among citizens is premised on a dense set of social norms about appropriate behaviour-norms that are backed up by strong informal pressure that can on occasion result in a highly paternalistic and intrusive form of social discipline, as well as one that is potentially highly exclusionary of critics or outsiders.

Another distinguished work which advances a cultural explanation of the varying dynamics of penal policy in different countries -in this case, as between France and Germany on the one hand and the United States on the other-is James Whitman's Harsh Justice (2003). In his wide-ranging account, Whitman scrutinises the ways in which different histories of status distinction in Western Europe as distinct from the United States have produced longstanding differences in the level of tolerance of harsh state punishment, particularly in qualitative terms. In the revolutionary moments in which new legal orders emerged in France and Germany, a turn away from the ancien régime notion of punishment as a form of status degradation became a mark of modernisation and progress. These societies turned instead to a forward-looking and egalitarian conception of state punishment focused on reformation, itself premised on levelling treatment up to the standards regarded as appropriate to high status offenders. With no such impulse to mark a turn away from an indigenous-as opposed to colonial-oppressor, punishment in the US remained a form of status degradation in which it was thought appropriate to level standards down to the lowest compatible with safety and decency. (Or, as the Supreme Court decided in Brown v. Plata, 563 U.S. 493 (2011), sometimes even less.) Hence, Whitman's explanation for the acceptability of uniquely harsh and degrading penal policy in the US is importantly premised on the persistence of a cluster of attitudes, values and assumptions whose roots lie deep in American history. Similarly, the role of distinctive cultural attitudes and practices have been central to accounts of the role of factors such as race (Tonry 1995; Patillo-McCoy 1999; Patillo 2007; Alexander 2012) and religion (Cusac 2009) in influencing the development of penal policy.

These accounts and others like them are richly textured and suggestive in delineating distinctive attitudes to punishment among publics and policy-makers in different contexts. They perform less strongly, however, in generating robust explanations or insights into the precise causal mechanisms through which these cultural differences are sustained over time and shape the decisions of penal policy-makers. These weaknesses become particularly apparent in the comparative context, in which it is often possible to point to penal variation between countries displaying relatively similar cultural histories or features. For example, it is not clear how Whitman's argument can account for the large persisting gap between the US and England and Wales/Scotland in terms of toleration of harsh punishment, given that his status degradation argument would also seem applicable in Britain. Similarly, the remarkable realignment of Finland with what we might call a typical Nordic model of penal moderation from the $1970 \mathrm{~s}$ after a period of significantly greater resort to imprisonment seems highly unlikely to have been premised solely on a sudden cultural change, but rather a product of institutional capacities and political alignments premised on Finland's increasing 
orientation towards the Nordic region in the post-war era (Lappi-Seppälä 2007, 2012; Cavadino \& Dignan 2006: 160-167). Cultural dynamics do seem to be an important mechanism in the legitimation and stabilisation of ideas about penal policy; but is it plausible that those dynamics are independent of the institutional frameworks through which social order is produced and political decision-making is framed? Might cultural differences be important not only in underpinning institutions, but also-even, ratherbe produced or at least shaped by those institutional configurations?

\section{Penal Policy as Shaped by Structural Economic Forces ${ }^{2}$}

At the other end of the spectrum from cultural approaches, we have a family of theories which claim that penal policy is determined by material, structural forces within the economy. This approach finds its most thoroughgoing statement in Rusche and Kirchheimer's Punishmentand Social Structure (1969; see also Rusche 1933; Garland 1990), which draws out a structural account—or, perhaps, two accounts-from a Marxian history of the changing form of punishment. First, they argue, punishment plays a structural role in regulating labour: in a capitalist economy in particular, punishment operates not only to underpin the regime of private property rights but also to discipline a reserve army of labour-or, in more contemporary terms, to govern social marginality (Beckett and Western 2001). Hence, we would expect to see punishment rise during times of unemployment, and lower rates of punishment in times and places marked by high rates of employment: the more expendable a person's labour, the higher their chances being punished. This first account also purports to explain the changing forms of punishment over time. Imprisonment emerges under capitalism as an effective penal mechanism that can warehouse labour without destroying its potential value when next it is needed. In contrast, pre-capitalist societies in which life and labour were cheap were marked by corporal penalties that sometimes inflicted lasting incapacitation. Secondly, punishment has a clear ideological function in legitimising the capitalist system, construing as it does conduct often produced by the injustices of capitalism as moral wrongs deserving of censure and sanction. Intriguingly, the second of these accounts could be read as a cultural rather than a structural account, one which operates at the level of how the meaning of punishment is conveyed and understood, albeit with this affecting the materiality of power relations (as for example in the work of Douglas Hay (1975)).

The theory implicit in Rusche and Kircheimer's analysis is a paradigm example of a structural account, and it displays all the strengths of such accounts, as well as suffering from all their defects. Its main strengths are the insight that economic

\footnotetext{
2 There has also been considerable work on penal decision-making influenced by microeconomic theory, notably via the Chicago School, conducing to a view of penal policy-making as shaped by an overarching concern with efficiency -an approach which resonates with the Benthamite tradition as received into the social sciences. We leave this work aside because it does not tend to engage with the larger question of what factors shape decision-makers' perception of the goals and outcomes to be optimised, which is the key concern of any analysis of the determinants of penal policy.
} 
dynamics and power relations are highly likely to be one important determinant of penal policy, and the provision of a very clear explanatory thesis. Its main weaknesses track those of the Marxian tradition. Likely as it seems that economic factors are in play in penal policy-making, it seems very unlikely that they are the only factor, hence the monolithic/mono-causal nature of the theory is a major drawback. The underlying model is strongly determinist and like any functionalist account leaves little space for the role of agency, especially the role of particular reformers, interest groups or social movements in shaping the development of penal policy. The 'punishment as ideology' argument lacks a clear causal story and has more than a whiff of unsubstantiated conspiracy theory about it. And, last but by no means least, the theory is not borne out by the facts, with no simple relationship between unemployment rates or other indices of economic performance and imprisonment rates or other obvious indices of changing penal policy discernible in data from the countries under scrutiny here, and with doubt about the economic rationality of state investments in expensive penal infrastructure over time (Garland 1990: 105-10).

Indeed-and precisely because of the structural nature of the theory-as Figure 4 shows, it also tends to perform poorly when tested against comparative evidence. Countries with relatively similar economic systems and situations nonetheless feature striking variation in the extent and quality of penal policy-variation that in many cases persists over long periods of time. Even more recent accounts in this tradition (Melossi \& Pavarini 1981; De Giorgi 2006) suffer similar difficulties. A key example is Loïc Wacquant's Punishing the Poor (2009), which elaborates a broadly Marxian account in terms of sociologist Pierre Bourdieu's conception of the penal 'right' and welfarist 'left' hands of the modern state (Bourdieu 1992), which Wacquant sees as having gradually been restructured in favour of the former at the expense of the latter, largely due to the dynamics set up by a 'neoliberal', deregulated and fiercely competitive economy. Wacquant's is an eloquent critique of the inequalities and injustices of the American criminal justice system, but his overgeneralised conception of neoliberalism, its global reach and its penal policy upshot (De Giorgi 2006; Lacey 2010) suffers similar drawbacks to Rusche and Kirchheimer's more ostensibly unitary account. Wacquant's structural account of interests takes no account of the striking comparative variation among countries equally marked by neoliberalisation/deregulation: a variation strongly suggestive of the conclusion that interests are not exogenous in determining penal policy, but are rather shaped by, as well as shaping, ideas, as well as being realised within institutions which both shape interests and provide the conditions of existence of particular policy options. 
Figure 4. Imprisonment rates in advanced economies, 2014

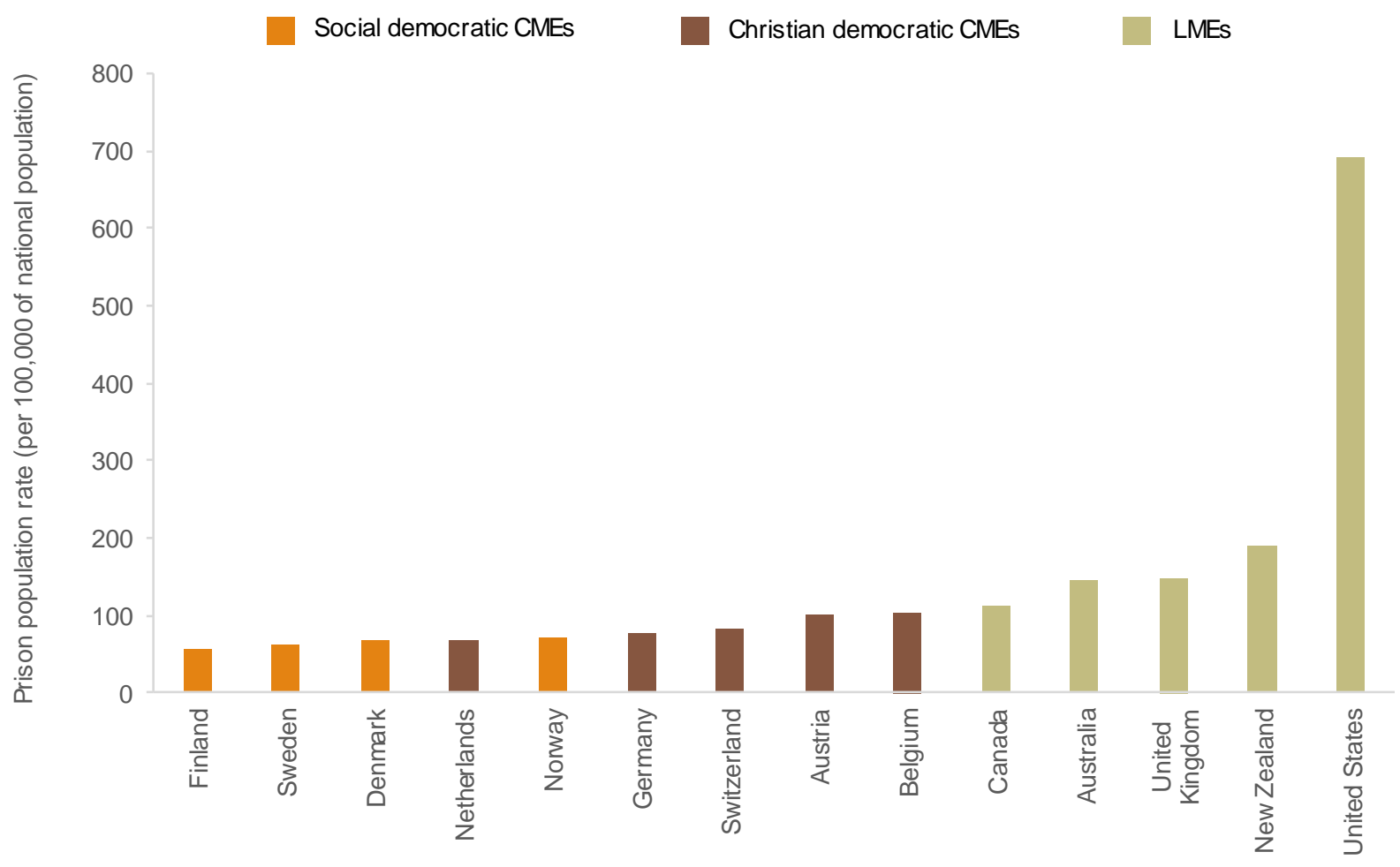

Note: $\mathrm{CME}=$ coordinated market economy; $\mathrm{LME}=$ liberal market economy .

Source: World Prison Brief, Institute for Criminal Policy Research (accessed Jan 2017).

\section{The Institutional Structure of the Political Economy as Shaping Penal Policy}

The structural accounts of what drives penal policy, deriving from the Marxian politicaleconomic tradition, are accordingly unsatisfactory. But this is not to say that they are without key insights. For it is clear that structural economic conditions within the context of changing technology regimes set key parameters for policy-makers-and moreover, prompt conditions for crime and for the development of cultural attitudes and attachments which any student of penal policy must grasp. We can see this if we focus on the importance in understanding what has happened-as well as the hints that it gives for the future-of one recent shift. This is the immense social and economic transformation of advanced societies in the past half century: a transition, far from complete, from the deeply embedded Fordist technological regime to that of the information era (De Giorgi 2006). Economic historians tell us how each of the great shifts in technological regimes since the early nineteenth century have changed most aspects of social existence (often with great conflict and pain as winners fight to preserve their gains and losers struggle for compensation and survival, entailing huge cultural and political as well as economic shifts) - even if they have been managed with more or less success by different advanced societies. As we will suggest, the slow collapse of Fordism has been of huge resonance in understanding the widespread rise 
in violent crime and in understanding the penal responses to it (albeit with great differences in magnitude). Equally the growth of the knowledge economy, partial though it still is, has arguably played a key role in the reduction of violent crime; and in consequence, as we have suggested, it was importantly responsible for reducing the rate of change of punishment. While the mechanisms are not yet fully understood, a major role has clearly been the regeneration-though not without social costs (Beckett \& Herbert 2009) —of the inner cities of major metropolises (especially those which had not been highly focused on particular sectors of manufacturing). But to understand the varying impact of these widespread and significant changes, we must attend closely to the institutional structures through which their impact is filtered in different national and regional contexts.

We have already pondered the striking fact that, though most advanced countries saw proportionately comparable rises in crime from the early 1970s to the mid 1990s (since when most countries have similarly experienced a significant drop in crime), their reactions in terms of punishment have been markedly different (as shown in Figure 1). These differences undermine mono-causal explanations based on the diagnosis of a 'neoliberal penality' grounded in factors such as a common reaction to the economic restructuring following the global economic crisis of the 1970s. One can subscribe to the important role of the collapse of Fordism through the 1970s and 1980s in generating both increasing violent crime and punishment. But, notwithstanding the increasing interdependence of national economies and common adoption of many aspects of neo-liberalism, advanced nations have maintained striking differences in penal policy (as well as many other aspects of policy, including the welfare state, labour market framework regulations and so on). Looking at the trajectory of punishment over time and space, we can see a number of patterns, widely noted in the sociological literature: countries with lower levels of inequality, more generous welfare states, higher levels of unionisation and higher levels of social trust, for example-all factors likely to have been shaped by the political economy broadly understood-show consistently lower rates of imprisonment (Sutton 2004; Downes \& Hansen 2006; Zimring \& Johnson 2006; Savage et al. 2008). The challenge is to move from an observation of these correlations to an explanation of how they were reproduced over time, even amid common pressures created by a globalising economy. The institutional structure and modus operandi of political-economic systems-labour markets, political systems, welfare states-is, we suggest, an obvious place to look.

Drawing on work by Iversen and Soskice which examines the political underpinnings of different forms of capitalism (Iversen and Soskice 2006, 2009), Lacey (2008, 2010, 2012) has argued that the structure of electoral competition in winner-takes-all, first past the post systems like that of England and Wales or of the US tends under certain conditions to produce what we might call a law and order arms race between the two main parties. This argument about political systems was nested within the 'varieties of capitalism' distinction between 'liberal' and 'co-ordinated' market economies (Hall \& 
Soskice 2001). A 'co-ordinated market economy' functions in terms of long-term relationships and stable structures of investment, not least in education and training oriented to company- or sector-specific skills, and incorporates a wide range of social groups and institutions into a highly co-ordinated governmental structure, including a generous welfare state on either 'social democratic' or 'continental' lines in EspingAndersen's terminology (Esping-Andersen 1990, 1996). Such systems are more likely to generate incentives for the relevant decision-makers to opt for a relatively inclusionary criminal justice system. For they are premised on incorporation, and hence on the need to reintegrate offenders into society and economy-making them structurally less likely to opt for exclusionary stigmatization in punishment. Typically, moreover, the interlocking and diffused institutions of co-ordination of the co-ordinated market economies of northern Europe and the Nordic region conduce to an environment of relatively extensive informal social controls, and this in turn supports the cultural mentalities which underpin and help to stabilise a moderated approach to formal punishment.

A 'liberal market economy' is typically more individualistic in structure, is less interventionist in economic regulation, depends far less strongly on the sorts of coordinating institutions that are needed to sustain long term economic and social relations, and features less extensive welfare provisions. In these economies, flexibility and radical innovation, rather than stability and investment, form the backbone of comparative institutional advantage. It follows that, particularly under conditions of surplus unskilled labour-conditions that liberal market economies are also more likely to produce-the costs of a harsh, exclusionary criminal justice system are less than they would be in a co-ordinated market economy. Britain and the US, of course, fit firmly within the typology of an individualistic, liberal market economy. The resulting empirical relationship between labour market regime and penal harshness as measured by the imprisonment rate is illustrated in Figure 4.

Where do political systems fit into this account? The organization of political systems varies widely of course, between both countries and sub-national regions (Tonry (ed.) 2007; Tonry 2007; Lacey 2008: Chapters 2-4; Barker 2009; McAra 2011). But it is striking that the two families of capitalist system turn out to be distinguished not only by differently structured production regimes and welfare states (Esping-Andersen $1990,1996)$, but also by different types of polities. The co-ordinated market economies feature, without exception, proportionally representative electoral systems, and the liberal market economies, with a small number of exceptions, first past the post, majoritarian systems. These differences support parties in co-ordinated market economics which are more strongly interest-based - with close links to unions, business associations and other more organised groups - than the leadership-based parties of liberal market economies. This makes a substantial difference to criminal justice in several ways. Of indirect but real importance, the structure of the political system affects the capacity to build coalitions capable of providing support for long term investment in institutions such as the welfare state, the education system and the 
more welfarist versions of criminal justice intervention whose benefits are hard to quantify and are realised only in the medium or long term. More directly, the shape of the political system affects the ways in which perceived anxiety about crime or insecurity register in the electoral process. In longstanding proportionately representative systems, there are significant constraints on executive power, as well as robust institutional arrangements facilitating co-ordination between settled interests and underpinning, in Lijphart's terms (1984), a consensus orientation in politics. In 'first past the post' systems, by contrast, a typically adversarial and individualistic political culture, along with a decline in electoral turn-out, particularly among younger and less advantaged voters, and a reduction in the number of voters who identify consistently with a particular party, have fostered the volatility of law and order politics amid an unedifying scramble for the support of the 'floating' or the reluctant voter. There is thus a fundamental difference between consensus/negotiated and majoritarian/competitive polities (Lijphart 1984, 1999).

Features of political systems therefore conduce to-or militate against-support for the economic and social policies which make it easier for governments to pursue inclusionary criminal justice policies. In liberal market economies with majoritarian electoral systems - particularly under conditions of relatively low trust in politicians and declining electoral turn-outs, diminishing deference to the expertise of criminal justice professionals, a reduction in the proportion of the electorate who vote on stable party lines, and candidates for office consequently focused on the resultant 'floating' (or potentially abstaining) voter-the unmediated responsiveness of politics to popular opinion in the adversarial context of a two party system makes it harder for governments to resist a ratcheting up of penal severity wherever key voters become concerned about crime. These dynamics are accentuated where both parties take up a law and order agenda (Downes \& Morgan 2007; Newburn 2007), and where-as in the UK and the US over much of the last half century-economic inequality and insecurity have fed popular anxiety about crime, marking out penal policy as a platform on which politicians from all points of the political spectrum may appeal to undecided voters. The result is, loosely speaking, a 'prisoners' dilemma' in which neither party can afford, electorally, to abandon its tough stance, while everyone (other than those, not insignificant, groups with a financial interest in the prison build-up) loses from the increasing human and economic costs of an ever more punitive system (Lacey 2008).

\section{The United States in Political-Economic Perspective}

Over the last decade, much of the debate about the relevance of political-institutional structure has focused on the United States, in light of its quite exceptional trajectory in penal policy. Michael Tonry $(1995,2004,2007,2013)$ has analysed not only the impact of the politics of race but also that of a constitutional structure which places few restraints on the substance of criminal policy; of the separation of powers; and of the relative insulation from politics of the policy-making process (see also Savelsberg 
1994, 1999). Marie Gottschalk $(2006,2015)$ has traced the shifting role of criminal politics in American history, pointing up a gradual accretion of institutional capacity which ultimately underpinned the prison expansion of the late $20^{\text {th }}$ Century, and a political structure in which the preferences of a distinctively punitive victims' movement registered strongly. These dynamics have in Gottshalk's view led to the creation of a powerful prison state that will be hard to dismantle. Lisa Miller $(2008,2016)$ has shown how the dynamics of criminal justice policy-making differ as between the federal, state and local levels of the multi-tiered American political system, as well as how the fragmented political structure has obstructed efforts at moderating reform. Vanessa Barker's (2009) study of California, New York and Washington has shown the way in which different governance structures have contributed to large regional disparities in patterns of punishment. Barker shows that, interacting with the history and culture of state politics, those structures shape varying-populist, managerialist or deliberative-traditions of political participation which imply markedly different capacities for collective agency. Both David Garland and Jonathan Simon have argued that waning confidence in the political capacity to manage the economy, alongside the relatively straightforward process of demonstrating governmental competence through tough law and order policy, has accentuated the tendency to 'govern through crime' and enhanced the executive power of officials such as prosecutors (Garland 2001; Simon 2007). And the decentralization of the US political system, which causes problems for any national reform movement, is an important factor in Garland's analysis of American retention of capital punishment (Garland 2010). Franklin Zimring (2007) has studied the impact of local policy-making on the 'great crime decline' and has noted that the fact that (most) criminal justice policy-making is divided between local and state levels has implications for how effectively costs, or a reduction in costs, register in the political process: for example, the penal cost-savings produced by an effective crime prevention strategy at the local level have to be massive before they register with policy-makers at the state level (Zimring 2012: Appendix B; Stuntz 2011).

Moreover, a developing literature exploring the various links between crime and punishment and politically relevant economic factors such as wage rates (Bound \& Freeman 1992; Boggess \& Bound 1993; Freeman 1996; Fagan \& Freeman 1999; Western and Beckett 1999; Gould et al. 2002; Machin \& Meghir 2004) is raising questions about the causal relevance of institutional factors, although studies in this area have tended so far to be mono-causal, and relatively little attention has been paid to the ways in which individual incentives and motivations may be influenced by institutional structures and settings. Lacey \& Soskice (2015) have focused on the institutional structure of the political system, arguing that the uniquely decentralised American system, which accords a distinctive degree of autonomy to localities, and which governs a distinctively wide range of decisions about education, zoning and criminal justice through local electoral politics, produces a polarising dynamic in which it is impossible to garner stable political support for integrative, let alone redistributive policies (Table 1). The key 'median' voters in local elections are, disproportionately, home-owners - 'home-voters' in Fischel's $(2004,2005)$ terminology-who vote for 
policies which will maximise their own property values and the quality of services and the environment in their immediate area, and who are reluctant to vote for costly public goods whose benefits are not so restricted. This implies the critical importance of residential 'zoning ordinances', more or less unique to the American system, voted on at local level, and establishing upper limits within a zone on houses per acre and on family units per house. In this light, it is electorally rational for local politicians and candidates for local office in municipal governments, school districts and the criminal justice system to form policies based on zoning: whether of good schools, of community policing, of public housing, or-the most extreme example-of offender populations into the prison system. These dynamics, moreover, have become particularly strong since the collapse of Fordism and disappearance of many manual jobs which formerly provided a bridge from education to employment for the lowskilled.

Table 1. Levels of political decision-making in liberal market economies

\begin{tabular}{|c|c|c|c|c|c|}
\hline & Police & Prosecutors & $\begin{array}{l}\text { Local } \\
\text { judges }\end{array}$ & Zoning & Schools \\
\hline US & $\begin{array}{l}\text { City/municipal } \\
\text { appointment by } \\
\text { mayor } \\
\text { (sometimes } \\
\text { elected) }\end{array}$ & $\begin{array}{l}\text { DA elected } \\
\text { county or } \\
\text { multi- county } \\
\text { district }\end{array}$ & $\begin{array}{l}\text { Most states } \\
\text { elected on } \\
\text { county or } \\
\text { multi-county } \\
\text { district }\end{array}$ & $\begin{array}{l}\text { Zoning } \\
\text { Boards } \\
\text { appointed by } \\
\text { locally elected } \\
\text { Council/Mayor }\end{array}$ & $\begin{array}{l}\text { Property tax } \\
\text { by elected } \\
\text { School Board } \\
\text { at School } \\
\text { District }\end{array}$ \\
\hline Canada & $\begin{array}{l}\text { Office of } \\
\text { Provincial AG; } \\
\text { operating } \\
\text { procedures, } \\
\text { appointments, } \\
\text { training }\end{array}$ & Provincial AG & $\begin{array}{l}\text { Provincial } \\
\text { government }\end{array}$ & $\begin{array}{l}\text { Provincial, } \\
\text { Federal } \\
\text { defined } \\
\text { policies }\end{array}$ & $\begin{array}{l}\text { Provincial } \\
\text { policies }\end{array}$ \\
\hline $\begin{array}{l}\text { England \& } \\
\text { Wales }\end{array}$ & $\begin{array}{l}\text { Home Office } \\
\text { appoints Chief } \\
\text { Constables }\end{array}$ & $\begin{array}{l}\text { Attorney } \\
\text { General } \\
\text { (government } \\
\text { agency) }\end{array}$ & $\begin{array}{l}\text { Lord } \\
\text { Chancellor } \\
\text { (Ministry of } \\
\text { Justice) }\end{array}$ & $\begin{array}{l}\text { Min Housing } \\
\text { rules, right of } \\
\text { appeal to } \\
\text { Minister }\end{array}$ & $\begin{array}{l}\text { National } \\
\text { government } \\
\text { policies }\end{array}$ \\
\hline NZ & $\begin{array}{l}\text { Government } \\
\text { appoints (under } \\
\text { Minister of } \\
\text { Police, } \\
\text { prosecution } \\
\text { independence) }\end{array}$ & $\begin{array}{l}\text { Attorney } \\
\text { General } \\
\text { appoints } \\
\text { (remain } \\
\text { private } \\
\text { lawyers) } \\
\text { national } \\
\text { guidelines }\end{array}$ & $\begin{array}{l}\text { Attorney } \\
\text { General }\end{array}$ & $\begin{array}{l}\text { National } \\
\text { guidelines }\end{array}$ & $\begin{array}{l}\text { National } \\
\text { system } \\
\text { (Ministry of } \\
\text { Education) }\end{array}$ \\
\hline
\end{tabular}

Source: Lacey \& Soskice (2017). 


\section{The History and Politics of Race: A Case Study}

It is disturbing, but nonetheless true, that race presents a telling case study in assessing the relative strengths of the four paradigms seeking to explain the genesis of penal policy. The over-representation of certain ethnic groups, notably young black men with low educational qualifications, is a marked phenomenon in the criminal justice systems of many countries, with the disproportion in England and Wales for example corresponding to that in the US. But the much larger population of AfricanAmericans in the US than of black Britons in the UK entails a more noticeable impact on overall prison numbers, and the significant increase in the disproportionate imprisonment of black Americans during the era of mass incarceration has accordingly turned the spotlight onto the American case. In 2010, the incarceration rate for blacks and Hispanics was 4.6 that for whites, a return to its 1970 level from a high of 6.8 times the white level in 1990 (National Research Council 2014: 56-59). These alarming disparities have tempted some scholars to think of race as itself a determinant of penal policy of independent importance. But the baleful influence of race on penal practices can only be explained through a combination of the arguments about culture, crime and political economy developed in the paradigms set out above.

To see why race alone is a poor candidate as an independent factor in explaining how penal policy is determined, it is instructive to compare the United States with New Zealand-a country which has, in its Maori population, an even more disadvantaged minority of similar relative size, and which exhibits comparable over-representation of that minority in both crime and punishment: while Maori constitute $15 \%$ of the New Zealand population, they make up $51 \%$ of its prison population (Pratt \& Clark 2005; New Zealand Department of Corrections 2007). Moreover, most observers of New Zealand's white culture would regard it as having significant racist elements. Yet we see in New Zealand nothing approaching the scale overall of crime, punishment or segregation which pertains in the US (Johnston et al. 2005, 2007). Though this does not exclude the possibility that race has an independent impact on the overall pattern and scale of American punishment, it is also worth noting that, if we remove blacks from the US imprisonment figures for 2010, the rate remains about three times the level in England and Wales and two and a half times that in New Zealand (Lacey \& Soskice 2017). Even with Hispanics too removed from the prison figures, the rate remains about double that in England and Wales and one and a half times that in New Zealand. The legacy of a vicious history of racism, even reinforced with continuing worries about discrimination, is, pace many commentators (e.g. Tonry 1995, 2011; Alexander 2012) not enough in itself to explain American crime and punishment.

How, then, might we draw on the paradigms set out above to explain why such marked racial disparities emerge from penal policy without themselves counting as primary explanatory factors? To begin with cultural factors: it is, unfortunately, clear that a cluster of social attitudes which denigrate certain ethnic or racial groups remain a 
powerful force in society, and it would be surprising if they did not have an impact on both the formulation of penal policy and the environment and climate of opinion in which policy-makers and those who implement policy operate. These effects show up particularly strongly in the US system, with its relatively high black and Hispanic population and its long history of racial oppression and institutional discrimination (King 2000; King \& Smith 2005, 2011; Alexander 2012). But it is equally clear that this history interacted with patterns of economic development: their relatively recent achievement of formally equal civil rights and hence formally equal entry into the education system and labour market meant that black Americans and, to a somewhat lesser extent, Hispanics suffered particularly acutely from the labour market changes of the 1970s and 1980s. This tragic collision between economic forces and the continuing legacy of racism, put African Americans in precisely the wrong place (poor areas in large cities) at precisely the wrong time (during the collapse of industrial production) (Wilson 1987, 1996; Allen \& Farley 1986). Sampson and Wilson are right to insist that there is 'more than just race' at work here for poor blacks trapped in the densely populated 'bad' inner city zones: race and class are inextricably linked in the production of the persisting and devastating intersectional disadvantages still encountered by African Americans in criminal justice, education, housing and beyond (Sampson \& Wilson 1995, Wilson 2009).

The stark facts of racial inequality in the US, as graphically charted by scholars like Wilson (1987), Massey \& Denton (1993), Loury (2003, 2010), Western (2006) and Alexander (2012) are direct and indirect consequences of racism in (and before) the 19th Century (Charles 2006: Chapter 6; Aaronson 2014) and the continuing echoes of slavery, the Jim Crow regime which replaced it, and a host of associated institutional arrangements, notably in relation to policing (Muller 2012). This reverberating history, moreover, has helped to produce real disparities in crime (National Research Council 2014: 59) (as indeed of criminal victimization: Miller 2016), albeit that the former have declined somewhat since the 1970s, particularly in relation to violent crime (National Research Council 2014: 57).

These disparities, importantly, have been fed by exceptionally high levels of residential segregation, which undermines the sorts of social capital that can help to prevent crime (Petersen \& Krivo 2010; Sampson 2012), along with the lack of any real educational escape for the truly disadvantaged. And this has been exacerbated by the social disorganization attendant on the demographic implications of mass migration and, later, the gradual exit, whether to suburbs or to contiguous areas (Pattillo-McCoy 1999), of the black middle class Wilson (1987). Many of the policies which have produced these effects have been consequences of local median voters' choices under conditions of radical local autonomy, and they can only be explained in terms of the institutional structure of the decentralized American political system, whose centrifugal dynamics set up by local autonomy have driven demographic divisions within as well as between racial groups (Charles 2006), just as they have given local black political leaders disincentives to combat segregation (Massey \& Denton 1993: 
153-60, 213-15). Once divisions of disadvantage become mapped onto space, the possibilities of reversal—notably through educational achievement—steadily diminish.

Table 2. American exceptionalism in adverse social outcomes

\begin{tabular}{|c|c|c|c|c|c|c|}
\hline & $\begin{array}{l}\text { United } \\
\text { States }\end{array}$ & $\begin{array}{l}\text { United } \\
\text { Kingdom }\end{array}$ & Australia & $\begin{array}{l}\text { New } \\
\text { Zealand }\end{array}$ & Canada & Sweden \\
\hline $\begin{array}{l}\text { Residential } \\
\text { Segregation: } \\
\text { (Ethnic) (2000-01) }\end{array}$ & $\begin{array}{l}10.8 \\
{[11.4]} \\
\text { Black }\end{array}$ & $\begin{array}{l}1.7 \\
{[9.9]} \\
\text { S. Asian }\end{array}$ & $\begin{array}{l}0.1 \\
{[2.7]} \\
\text { Asian }\end{array}$ & $\begin{array}{l}0.0 \\
{[19.6]} \\
\text { Maori }\end{array}$ & $\begin{array}{l}1.4 \\
{[11.2]} \\
\text { Asian }\end{array}$ & - \\
\hline $\begin{array}{l}\text { Prison population rate } \\
\text { (per 100,000) (2012) }\end{array}$ & 707 & 153 & 130 & 195 & 118 & 67 \\
\hline $\begin{array}{l}\text { Homicide rate } \\
\text { (per 100,000) (2012) }\end{array}$ & 4.7 & 1.0 & 1.1 & 0.9 & 1.6 & 0.7 \\
\hline $\begin{array}{l}\text { Literacy score }\left(5^{\text {th }}\right. \\
\text { percentile) }(2012)\end{array}$ & 182.0 & 188.0 & 193.3 & - & 185.1 & 188.2 \\
\hline Child poverty (2009) & 23.1 & 12.1 & 10.9 & 11.7 & 13.3 & 7.3 \\
\hline
\end{tabular}

Notes: Residential segregation: \% population in large cities living in tracts where (a) $>70 \%$ ethnic, (b) one ethnic group dominant, (c) $>30 \%$ of group in city live in these tracts. The number in [] is $\%$ of main ethnic group in cities analysed. The black percentage in the US big-city sample is less than the percentage in the US population (because of the South), while the Maori percentage is less; both around 15 percent of the population. The prison population rate and homicide rate for the UK refer to England and Wales only. The child poverty measure is the percentage of children aged 0-17 in households where disposable income (corrected for family size/composition) $<50$ percent median.

Source: Johnston et al. (2007); World Prison Brief, Institute for Criminal Policy Research (accessed Jan 2017).; United Nations Office on Drugs and Crime: Global Study on Homicide 2013; UK Office for National Statistics (data accessed Feb 2017); OECD (2013); UNICEF (2012).

The resulting tragedy of entrenched segregation did not happen on the same scale in systems where policing, planning and education policy are developed at national level (for comparative differences, see Table 1). For example, the degree of racial residential segregation in America has been shown to be substantially higher than that in the UK, Australia or New Zealand (Johnston et al. 2005, 2007) (as shown in Table 2). This can hardly be thought to be because other Anglo-Saxon countries are strangers to racism or indeed to discriminatory public policy. The UK introduced an implicitly colour-based 'Nationality' (i.e. Immigration) Act in 1971, and introduced comprehensive race discrimination legislation only in 1976, 12 years after the Civil Rights Act of 1964. Australia abolished the last elements of the White Australia immigration policy which had prevailed since the beginning of the $20^{\text {th }}$ Century only in 1973. Perhaps most striking, New Zealand, whose Maori population is comparable to the black American population in terms of both proportionate size and social and economic disadvantage, and is over-represented in the prison population to a similar 
degree (New Zealand Department of Corrections 2007), had a White New Zealand immigration policy until 1986. Yet Maoris have been integrated into the cities in which they are most populous, notably Auckland, about twice as completely (in terms of residential segregation) as American blacks. In America's radically decentralized system, it is impossible to frame and find consistent support for political strategies to combat segregation. And without such policies, racial disadvantage will continue to accumulate, with the segregation-promoting dynamics of local politics consolidating the problem of black and Hispanic disadvantage, creating what Miller (2016) has called 'racialised state failure'. Indeed, this is consistent with Peterson \& Krivo's findings (2010) that higher segregation is accompanied by higher levels of violence across the city. American localism cannot be argued to have been motivated by, racism; but it has, unfortunately, had particularly striking effects in consolidating the disadvantage of certain groups, notably blacks and Hispanics.

A key problem therefore lies in the local political institutions which have driven and sustained socio-economic segregation, and which have in doing so subverted not only the ideals of the Civil Rights Movement but any real prospect of alleviating poverty and disadvantage in the absence of state or federal initiatives. In the face of these dynamics, the main tools for national policy-making and for the implementation of national policy at local level-the provision of federal grants to localities; the institution of regulatory agencies to produce and/or monitor standards; and the enforcement of constitutional standards in the courts-have proved weak or even impotent The racial justice to which the Civil Rights Movement aspired remains distant, as social outcomes in education, crime, punishment and housing clearly attest. The determination of the penal policies that have exacerbated these outcomes have certainly to do with racial cultural attitudes, disparities in patterns of crime, and economic forces and shocks; but an equally fundamental determinant has been the polarising dynamics set up by the filtering of political preferences through the institutional structure of the radically decentralised American political system, within the context of the US as an extreme instance of a liberal market economy.

\section{Conclusion}

We have underlined the profound social and economic shifts characterising the advanced economies over the last half-century, from the gradual painful collapse of Fordism to the development of the knowledge economy. These we suggested explained both the rise in crime, particularly in violent crime, in the 1970s and 1980s, and the subsequent decline since the mid-1990s. The development of penal policy needs to be seen against this background. As we have shown, superimposed on these large secular shifts have been profound cross-country differences. Existing research in the advanced economies has made significant progress in shedding light on how structural, cultural and institutional factors coalesce to shape the political agency that produces penal policy. Valuable as the insights of these paradigms are, 
the comparative political economy model, with its close attention to institutional particularities and their concrete shaping of incentives, provides in our view the most promising framework in terms of bringing them together. For, more fully developedas sketched in relation to our case study of race-it can help to explain the production of crime patterns and responses to them; the way in which cultural factors are filtered and countered or reinforced in particular settings; the ways in which common economic shocks are refracted differently and produce varying incentives to actors and groups in differently configured political systems. There remains much detailed empirical work to be done to test out the hypotheses emerging from this work: even in systems in which the most work has been done, much remains to be understood. Here, the United States offers and endlessly fascinating, as well as troubling, case; not least because of the huge degree of regional variation (Newburn 2010), which offers opportunities for testing causal theses in areas with similar cultural, economic and social features but differing institutional structures.

Two different broad challenges are emerging. First, if knowledge economies have arguably reduced crime, this raises a new puzzle: for the losers from the growth of knowledge economies are widely seen as receptive to populist politics. As European experience is showing, this is quite different from neo-liberalism. So, an obvious question in relation to the US and more generally elsewhere is the implications of the emerging forms of populism for penal policy.

Second, and yet more obviously, there remains the challenge of adapting existing models or creating new ones to explain how penal policy is determined in emerging economies and transitional systems such as those of South America, South Africa or Eastern Europe (Iturralde 2007; Sparks et al. (ed.) 2011; Whitfield 2016), or indeed in the mixed market economies of Southern Europe (Gallo 2015; Cheliotis \& Xenakis 2016). Important work, including on political economy models on which comparative criminologists might build, is beginning to emerge (see, for example, Schneider 2013). There is every prospect that the significant strides made over recent decades in our understanding of both the broad factors that determine penal policy and the causal mechanisms through which they work, will be more than matched over the decades to come. 


\section{Literature Cited}

Aaronson E. 2014. From Slave Abuse to Hate Crime: The Criminalization of Racial Violence in American History. New York: Cambridge University Press Alexander M. 2012. The New Jim Crow. Mass Incarceration in the Age of Colourblindness. New York: The New Press

Allen WR, Farley R. 1986. The shifting social and economic tides of Black America 1950-1980. Annual Review of Sociology. 12:277-306 American Academy of Arts and Sciences. 2010. The Challenge of Mass Imprisonment in America Daedalus. 139(3)

Barker V. 2009. The Politics of Punishment: How the Democratic Process Shapes the Way America Punishes Offenders. New York: Oxford University Press

Barker V. 2013. Nordic Exceptionalism revisited: Explaining the paradox of a Janus faced penal regime. Theoretical Criminology. 17(1):5-25

Beccaria C. 2009. [1764]. On Crime and Punishments. United States of America: Seven Treasures Publications

Becker H. 1973. [1963]. Outsiders. New York: Free Press

Beckett K. 1997. Making Crime Pay. New York: Oxford University Press

Beckett K, Western B. 2001. Governing Social Marginality. In Mass Imprisonment: Social Causes and Consequences, ed. D Garland, pp. 35-50. London: Sage

Beckett K, Herbert S. 2009. Banished: The New Social Control in Urban America. New York: Oxford University Press

Bentham J. 1970. An Introduction to the Principles of Morals and Legislation (ed. HLA Hart, JH Burns [1781] London: Athlone Press. (2 ${ }^{\text {nd }}$ Ed, Oxford: Clarendon Press, 1996))

Birkel C, Dern H. 2012. Homicide in Germany. In Handbook of European Homicide Research, ed. MCA Liem, WA Pridemore, pp. 313-328. Springer: New York

Boggess S, Bound J. 1993. Did Criminal Activity Increase During the 1980s? Comparisons across Data Sources. National Bureau of Economic Research Working Paper, no. 4431 
Bound J, Freeman R. 1992. What Went Wrong? The Erosion of Relative Earnings and Employment among Young Black Men in the 1980s. Quarterly Journal of Economics. 107:201-32

Bourdieu P. 1992. The Left Hand and the Right Hand of the State. http://www.variant.org.uk/32texts/bourdieu32.html (accessed 6 February 2017)

Cavadino M, Dignan J. 2006. Penal Systems: A Comparative Approach. London: Sage

Charles CZ. 2006. Won't You Be My Neighbour? Race, Class and Residence in Los Angeles. New York: Russell Sage Foundation

Cheliotis L, Xenakis S. 2016. Punishment and political systems: state punitiveness in post-dictatorial Greece Punishment \& Society. 18(3):268-300

Cusac AM. 2009. Cruel and Unusual: The Culture of Punishment in America. New Haven: Yale University Press

De Giorgi A. 2006. Rethinking the Political Economy of Punishment. Aldershot: Ashgate

Downes D. 1988. Contrasts in Tolerance. Oxford: Clarendon Press

Downes D, Hansen K. 2006. Welfare and Punishment in Comparative Perspective. In Perspectives on Punishment, ed. S Armstrong, L McAra, pp. 101-118. Oxford: Oxford University Press

Downes D, Morgan R. 2007. No turning back: the politics of law and order into the millennium. In The Oxford Handbook of Criminology (4th edition), ed. M Maguire, R Morgan, R Reiner, pp. 201-240. Oxford: Oxford University Press

Durkheim E. 1893. De la division du travail social. The Division of Labour in Society, Transl. WD Halls. New York: Free Press 1997

Durkheim E. 1902. Two Laws of Penal Evolution. L’Année Sociologique. 4:65-95

Elias N. 1978, 1982. [1939] The Civilising Process (i. The History of Manners; ii. State Formation and Civilization). Oxford: Oxford University Press

Enns PK. 2014. Replication data for: The Public's Increasing Punitiveness and Its Influence on Mass Incarceration in the United States, doi:10.7910/DVN/24827, Harvard Dataverse, V2 
Enns PK. 2016. Incarceration Nation. New York: Cambridge University Press

Esping-Andersen G. 1990. The Three Worlds of Welfare Capitalism. Cambridge: Polity Press

Esping-Andersen G. 1996. Welfare States in Transition. London: Sage

Fagan J, Freeman R. 1999. Crime and Work. Crime and Justice: A Review of Research. 25:225-90

Fischel WA. 2004. An Economic History of Zoning and a Cure for its Exclusionary Effects. Urban Studies. 41:317-340

Fischel WA. 2005. Politics in a Dynamic View of Land-Use Regulations: Of Interest Groups and Homevoters. The Journal of Real Estate, Finance and Economics. 31(4):395-403

Foucault M. 1977. Discipline and Punish (transl. A Sheridan) Harmondsworth: Penguin

Freeman RB. 1996. Why do so many young American men commit crimes and what might we do about it? Journal of Economic Perspectives. 10(1): 25-42

Gallo Z. 2015. Punishment, authority, and political economy: Italian challenges to Western punitiveness. Punishment and Society. 17(5): 598-623

Gallo Z, Lacey N, Soskice D. 2017 (forthcoming). Comparing Serious Violent Crime in the US and England and Wales: Why It Matters, and How It Can Be Done. In American Exceptionalism in Crime and Punishment, ed. K Reitz. New York: Oxford University Press

Garland D. 1985. Punishment and Welfare Aldershot: Dartmouth

Garland D. 1990. Punishment and Modern Society. Oxford and New York: Oxford University Press

Garland D. 1996. The Limits of the Sovereign State. British Journal of Criminology. 36(4):445-471

Garland D. 2001. The Culture of Control. Oxford: Oxford University Press 
Garland D. 2010. Peculiar Institution: America's Death Penalty in an Age of Abolition. New York: Oxford University Press and Cambridge Mass.: Harvard University Press

Garland D. 2017. Penal power: Its forms, functions and foundations. British Academy Law Lecture 2016 (forthcoming)

Gatrell VAC. 1994. The Hanging Tree: Execution and the English People. Oxford: Oxford University Press

Gottschalk M. 2006. The Prison and the Gallows. Cambridge: Cambridge University Press

Gottschalk M. 2015. Caught: The Prison State and the Lockdown of American Politics. Princeton: Princeton University Press

Gould ED, Weinberg BA, Mustard DB. 2002. Crime Rates and Local Labor Market Opportunities in the United States: 1979-1997. Review of Economics and Statistics. 84(1):45-61

Hall PA, Soskice D. 2001. An Introduction to the Varieties of Capitalism. In Varieties of Capitalism, ed. P Hall, D Soskice, pp. 1-68. Oxford: Oxford University Press

Hay D. 1975. Property, Authority and Criminal Law. In Albion's Fatal Tree, ed. D Hay, P Linebaugh, EP Thompson, pp. 17-63. Harmondsworth: Penguin

Ignatieff M. 1980. [1978]. A Just Measure of Pain: The Penitentiary in the Industrial Revolution 1750-1850. Harmondsworth: Penguin

Iturralde M. 2007. Order first, justice later: emergency criminal policy as a path towards development. The Colombian case. Oñati Journal of Emergent Socio-Legal Studies. 1(2):55-76

Iversen T, Soskice D. 2006. Electoral Institutions and the Politics of Coalitions: Why Some Democracies Redistribute More Than Others. American Political Science Review. 100:165-81

Iversen T, Soskice D. 2009. Distribution and Redistribution: The Shadow of the Nineteenth Century. World Politics. 61(3):438-86 
Johnston R, Poulsen M, Forrest J. 2005. Ethnic Residential Segregation Across an Urban System: The Maori in New Zealand 1991-2001. The Professional Geographer. 57:115-29

Johnston R, Poulsen M, Forrest J. 2007. The geography of ethnic residential segregation: a comparative study of five countries. Annals of the Association of American Geographers. 97(4):713-38

King DS, Smith RM. 2005. Racial Orders in American Political Development. American Political Science Review. 99(1):75-92

King DS, Smith RM. 2011. Still a House Divided: Race and Politics in Obama's America. Princeton, New Jersey: Princeton University Press

King, DS. 2000. Making Americans: Immigration, Race and the Origins of the Diverse Democracy. Cambridge, Mass.: Harvard University Press

Lacey N. 2008. The Prisoners' Dilemma: Political Economy and Punishment in Contemporary Democracies. Cambridge: Cambridge University Press

Lacey N. 2010. American Imprisonment in Comparative Perspective. Daedalus. 139(3):102-114

Lacey N. 2012. Political Systems and Criminal Justice: The Prisoners' Dilemma After the Coalition. Current Legal Problems. 65(1):203-239

Lacey N, Soskice D. 2015. Crime, punishment and segregation in the United States: The paradox of local democracy. Punishment \& Society. 17(4):454-481

Lacey N, Soskice D. 2017 (forthcoming). American Exceptionalism in Crime, Punishment, and Disadvantage: Race, Federalization, and Politicization in the Perspective of Local Autonomy. In American Exceptionalism in Crime and Punishment, ed. K Reitz. New York: Oxford University Press

Lappi-Seppälä T. 2007. Penal Policy in Scandinavia. In Crime, Punishment and Politics in a Comparative Perspective. Crime and Justice: A Review of Research Vol. 36, ed. M Tonry. Chicago: University of Chicago Press

Lappi-Seppälä T. 2012. Criminology, Crime and Criminal Justice in Finland. European Journal of Criminology. 9(2):206-222 
Lijphart A. 1984. Democracies: Patterns of Majoritarian and Consensus Governments in Twenty-One Countries. New Haven: Yale University Press

Lijphart A. 1999. Patterns of Democracy: Government Forms and Performance in Thirty-Six Countries. New Haven: Yale University Press

Loury GC. 2003. The Anatomy of Racial Inequality. Cambridge: Harvard University Press

Loury GC. 2010. Crime Inequality and Social Justice. Daedalus. 139:134-40

Machin S, Meghir C. 2004. Crime and Economic Incentives. The Journal of Human Resources. 39(4):958-979

Malinowski B. 1966. [1926]. Crime and Custom in a Savage Society. Totowa, New Jersey: Rowman and Allanheld

Massey DS, Denton NA. 1993. American Apartheid: Segregation and the Making of the Underclass. Cambridge: Harvard University Press

McAra L. 2011. The impact of multi-level governance on crime control and punishment. In International and Comparative Criminal Justice and Urban Governance, ed. A Crawford, pp. 276-303. Cambridge: Cambridge University Press

Mead GH. 1918. The Psychology of Punitive Justice. American Journal of Sociology. 23:577-602

Melossi D, Pavarini M. 1981. The Prison and the Factory. London: Macmillan

Miller LL. 2008. The Perils of Federalism: Race, Poverty, and the Politics of Crime Control. New York: Oxford University Press

Miller LL. 2016. The Myth of Mob Rule: Violent Crime and Democratic Politics. New York: Oxford University Press

Muller C. 2012. Northward Migration and the Rise of Racial Disparity in America Incarceration, 1880-1950. American Journal of Sociology. 118:281-326

National Research Council. 2014. The Growth of Incarceration in the United States: Exploring Causes and Consequences. Committee on Causes and Consequences of High Rates of Incarceration, J. Travis, B. Western, and S. 
Redburn, Editors. Committee on Law and Justice, Division of Behavioral and Social Sciences and Education. Washington, DC: The National Academies Press

Nelken D. 2010. Comparative Criminal Justice: Making Sense of Difference. London: Sage

Nelken D. 2016. Comparative Legal Research and Legal Culture: Facts, Approaches, and Values. Annual Review of Law and Social Science. 12(1):45-62

Newburn T. 2007. "Tough on Crime": Penal Policy in England and Wales. In Crime, Punishment and Politics in Comparative Perspective. Crime and Justice: A Review of Research Vol. 36, ed. M Tonry, pp. 425-470. Chicago: University of Chicago Press

Newburn T. 2010. Diffusion, Differentiation and Resistance in comparative Penality. Criminology and Criminal Justice. 10(4):341-52

New Zealand Department of Corrections. 2007. Over-representation of Maori in the criminal justice system: an explanatory report. Wellington, New Zealand

OECD. 2013. OECD Skills Outlook 2013: First Results from the Survey of Adult Skills. Paris: OECD Publishing

Pattillo-McCoy M. 1999. Black Picket Fences: Privilege and Peril among the Black Middle Classes. Chicago: Chicago University Press

Pattillo M. 2007. Black on the Block: The Politics of Race and Class in the City. Chicago: Chicago University Press

Pfaff JF. 2012. The Micro and Macro Causes of Prison Growth. Georgia State University Law Review. 28(4):1237-1271

Peterson RD, Krivo LJ. 2010. Divergent Social Worlds: Neighbourhood Crime and the Racial-Spatial Divide. New York: Russell Sage

Pratt J, Clark MC. 2005. Penal populism in New Zealand. Punishment and Society. $7(4): 303-22$

Pratt J. 2008a. Scandinavian Exceptionalism in an Era of Penal Excess: Part I The Nature and Roots of Scandinavian Exceptionalism. British Journal of Criminology. 48:119-37 
Pratt J. 2008b. Scandinavian Exceptionalism in an Era of Penal Excess: Part II Does Scandinavian Exceptionalism Have a Future? British Journal of Criminology, 48:275-292

Pratt J, Eriksson A. 2013. Contrasts in Punishment: An Explanation of Anglophone Excess and Nordic Exceptionalism. London: Routledge

Radzinowicz L, Hood R. 1990. The Emergence of Penal Policy in Victorian and Edwardian England. Oxford: Clarendon Press

Reiner R. 2007. Law and Order: An Honest Citizen's Guide to Crime and Control Oxford: Polity Press

Reiner R. 2016. Crime: The Mystery of the Common-Sense Concept. Cambridge: Polity Press

Roth R. 2009. American Homicide. Cambridge, Mass: The Belknap Press of Harvard University Press

Rothman D. 1971. The Discovery of the Asylum: Social Order and Disorder in the New Republic. Boston: Transaction Publishers

Rusche G, Kirchheimer O. 1968 [1939, in German]. Punishment and Social Structure. New York: Russell Sage

Rusche G. 1978. [1933]. Labor market and penal sanction. Crime and Justice. 10:2-8

Sampson RJ, Wilson WJ. 1995. Toward A Theory of Race, Crime and Urban Inequality. In Crime and Inequality, ed. J. Hagan, RD Peterson, pp. 37-54. Palo Alto: Stanford University Press

Sampson RJ. 2012. Great American City: Chicago and the Enduring Neighbourhood Effect. Chicago University Press

Savage JR, Bennett R, Danner M. 2008. Economic Assistance and Crime: A Cross National Investigation. European Journal of Criminology. 5(2):217-38

Savelsberg J. 1994. Knowledge, Domination, and Criminal Punishment. American Journal of Sociology. 99:911-43

Savelsberg J. 1999. Knowledge, Domination and Criminal Punishment Revisited. Punishment and Society. 1:45-70 
Scheingold SA. 2010. [1984]. The Politics of Law and Order: Street Crime and Public Policy New Orleans: Quid Pro Books

Schneider BR. 2013. Hierarchical Capitalism in Latin America: Business, Labor, and the Challenges of Equitable Development. New York: Cambridge University Press

Simon J. 2007. Governing through Crime: How the War on Crime Transformed American Democracy and Created a Culture of Fear. New York: Oxford University Press

Sparks R, Melossi D, Sozzo M, ed. 2011. The travels of the CriminalQuestion. Cultural Embeddedness and Diffusion. Oxford: Hart Publishing

Spierenburg P. 1984. The Spectacle of Suffering: Executions and the Evolution of Repression. Cambridge University Press

Stuntz WJ. 2011. The Collapse of American Criminal Justice. Cambridge: Harvard University Press

Sutton J. 2004. The Political Economy of Imprisonment in Affluent Western Democracies, 1960-1990. American Sociological Review. 69:170-89

Tonry M. 1995. Malign Neglect: Race, Crime and Punishment in America. New York: Oxford University Press

Tonry M. 2004. Thinking about Crime: Sense and Sensibility in American Penal Culture. New York: Oxford University Press

Tonry M. 2007. Determinants of Penal Policies. In Crime, Punishment and Politics in a Comparative Perspective. Crime and Justice: A Review of Research Vol. 36, ed. M Tonry, pp. 1-48. Chicago: University of Chicago Press

Tonry M, ed. 2007. Crime, Punishment and Politics in a Comparative Perspective. Crime and Justice: A Review of Research Vol. 36. Chicago: University of Chicago Press

Tonry M. 2011. Punishing Race: A Continuing American Dilemma. New York: Oxford University Press

Tonry M. 2013. Crime and Justice in America, 1975-2025. Crime and Justice. Vol. 42. Chicago: Chicago University Press 
Tonry M, Lappi-Seppälä T, ed. 2012. Crime and Justice in Scandinavia. Crime and Justice: A Review of Research, 40

UNICEF. 2012. Measuring Child Poverty: New League Tables of Child Poverty in the World's Rich Countries. UNICEF Innocenti Research Centre

United Nations Office on Drugs and Crime (UNODC). 2014. Global Study on Homicide 2013 (United Nations Publication, Sales No. 14.IV.1)

von Hofer H, Lappi-Seppälä T, Westfelt L. 2012. Nordic Criminal Statistics 1950-2010: Summary of a Report. 8th revised edition. Kriminologiska Institutionen Stockholms Universitet

Wacquant L. 2009. Punishing the Poor: The Neoliberal Government of Social Insecurity. Durham: Duke University Press

Western B. 2006. Punishment and Inequality in America. New York: Russell Sage

Western B, Beckett K. 1999. The US penal system as a labour market institution. American Journal of Sociology. 104:1030-1060

Whitfield J. 2016. Other Neoliberal Penalities: Marching Pouder and Prison Tourism in La Paz. Theoretical Criminology. 20(3):385-75

Whitman JQ. 2003. Harsh Justice. Oxford: Oxford University Press

Wilson WJ. 1987. The Truly Disadvantaged: The Inner City, the Underclass and Public Policy. Chicago: Chicago University Press

Wilson WJ. 1996. When Work Disappears: The World of the New Urban Poor New York: Knopf

Wilson WJ. 2009. More than Just Race. New York: W.W. Norton

World Prison Brief, Institute for Criminal Policy Research (accessed Jan 2017).

Zimring FE. 2007. The Great American Crime Decline. Oxford: Oxford University Press

Zimring FE. 2012. The City that Became Safe. Oxford: Oxford University Press 
Zimring FE, Johnson D. 2006. Public Opinion and the Governance of Punishment in Democratic Political Systems. Annals of the American Academy of Political and Social Science. 605:266-80

Zimring FE, Hawkins G. 1997. Crime is not the Problem: Lethal Violence in America. New York: Oxford University Press 